\title{
Kölcsönösen átjárható városi, - és elővárosi vasúti rendszerek globális forgalmi hatásainak komplex vizsgálata
}

\section{Molnár Levente ${ }^{1}$, Vinkó Ákos ${ }^{1}$, Vasvári Gergely ${ }^{1}$}

\author{
${ }^{1}$ Budapesti Müszaki és Gazdaságtudományi Egyetem, Út és Vasútépítési \\ Tanszék \\ E-mail: m1levi12@gmail.com; vinko.akos@emk.bme.hu; \\ gergely.vasvari@outlook.com
}

DOI: $\underline{10.36246 / U L .2021 .1 .02}$

\section{KIVONAT}

Budapest elővárosi és a városi vasúti közlekedési rendszere több eltérő szolgáltatási színvonalú és müszaki paraméterü, egymástól elszigetelt vasúti rendszert tartalmaz, amelyek integrálása elengedhetetlen a mai modern kor átszállásmentes utazási igényeinek való megfeleléshez, valamint a főváros fokozatosan növekvő agglomerációs forgalmának kiszolgálásához.

A cikkben bemutatásra kerül az M3-as metró és a Lajosmizsei vasútvonal átjárhatóságának komplex vizsgálata során alkalmazott forgalmi modellezési eljárás. Ennek segítségével lehetővé vált az integrált vasúti rendszer budapesti és agglomerációs közlekedésre vonatkozó forgalmi hatásának számszerüsítése. A beszámolóban a vasúti átjárhatóság kompatibilitási kérdései részletesen nem kerülnek ismertetésre, e cikk elsősorban az elképzelt integrált közlekedési rendszer forgalmi igény szempontjából történő minősítését tüzte ki célul.

A cikk Molnár Levente BSc hallgató TDK dolgozatának kivonata, amiben a Müszaki Egyetem több munkatársa, valamint külső konzulensek is segédkeztek.

Kulcsszavak: városi közlekedés, vasúti átjárhatóság, forgalmi szimuláció

\section{ABSTRACT}

The transport system of Budapest includes various entirely self-contained rail transit modes with different service levels and technical parameters, their integration is necessary to create an effective transport service for the growing conurbation of Budapest.

This article presents an analytical travel forecasting approach used in the complex study on the interoperability of the M3 metro and the Lajosmizse railway line. This made it possible to quantify the traffic impact of the proposed integrated railway system on the transport of Budapest and its conurbation. This report does not describe the compatibility issues of track and vehicle interfaces in detail, the main purpose of this article is to classify the proposed integrated transport system in terms of traffic demand and forecasting.

Keywords: local public transport, interoperable rail systems, traffic simulation

\author{
Molnár Levente \\ A Budapesti Müszaki Egyetem (BME) Építömérnöki kárának végzös BSc hallgatója. Fö érdeklödési \\ területe a vasúti rendszerek közötti átjárhatóság vizsgálata.

\section{Dr. Vinkó Ákos} \\ A Budapesti Müszaki és Gazdaságtudományi Egyetem (BME) Épitőmérnöki Karán az Út és Vasútépítési \\ Tanszék munkatársa. Fö kutatási területe a vasúti pályadiagnosztika.
}




\author{
Dr. Vasvári Gergely \\ A Budapesti Müszaki és Gazdaságtudományi Egyetem (BME) Építőmérnöki Karán az Út és Vasútépítési \\ Tanszék munkatársa. Fö kutatási területe a forgalmi modellezés.
}

\title{
1. BeVEzetés
}

Jelen kutatómunka Budapest vonzáskörzetén belül található kötöttpályás vasúti rendszerek közötti átjárhatóság müszaki és forgalmi feltételeivel, korlátaival foglalkozik.

A vasúti átjárhatóságnak - interoperabilitásnak - két szintjét különböztetjük meg. Az első szint az országok közötti átjárhatóságot teremti meg. Ennek kiemelkedő célja, hogy első sorban az Európai Unió tagállamai között olyan feltételeket teremtsen, hogy a vonatoknak ne kelljen a határállomásokon vesztegelniük mozdony és személyzetcsere miatt. Ezt a közeledést egységes szabályozás, többáramnemü mozdonyok, valamint egységes vonatbefolyásoló rendszerek hivatottak megoldani.

Az átjárhatóság második szintjét az országon belül eltérő vasútüzemek (nagyvasút, HÉV, metró, közúti villamos vasút) közötti kapcsolatként definiálhatjuk. Itt az átjárhatóság elsődleges célja a kevésbé hatékony vasúti rendszerek hatékonyabbá tétele, a vasútüzemek közötti átszállások számának csökkentése, valamint a potenciális utazási célok elérésének megkönnyítése. Világszerte számos ilyen vasúti rendszer kezd kiépülni, mert felismerték az átjárhatóságban rejlő potenciált, első sorban azokban a nagyobb városokban, ahol eltérő vasútüzemek találhatóak. Erre kiemelkedő hazai példa a szegedi vasútvillamos („Tram-train”), ahol a Szeged és Hódmezővásárhely között futó vasútvonal került összekötésre a Szegedi, valamint az újonnan épült Hódmezővásárhelyi villamosvonallal.

A kutatómunka során több lehetséges helyszín is kijelölésre került Budapest és az agglomerációja területén, ahol felmerült a lehetőség átjárható vasúti rendszerek létesítésére ${ }^{1}$. Ezek között szerepelnek már ismert, korábban tervező cégek által vizsgált lehetőségek, illetve több újonnan kijelöltek is. Ezen helyszínekre online Google Form alapú, összetett utazási igényfelmérő kérdőívek készültek az általános utazási szokások körvonalazása, valamint, az átjárhatóság létjogosultságának eldönthetősége érdekében. A javasolt helyszínek közül végül kiválasztásra került az M3-as metró és a Lajosmizsei vasútvonal összekötése, amely esetében komplex módon került vizsgálat alá az átjárhatóság megvalósításának lehetősége.

A témában, az infrastruktúra-építőmérnöki szemlélet következtében, kiemelt szerepet kapott a két vasúti rendszer közötti átjárhatóság müszaki szempontból történő vizsgálata. Ez magában foglalta a pálya- illetve jármüinfrastruktúra kompatibilitás vizsgálatát, melynek keretében az átjárhatóság technikai feltételei kerültek elemzésre. Ezt átfogó kutatómunka előzte meg, számos külföldi átjárható vasúti rendszer vizsgálatával [1]. A kutatómunka során folyamatosan konzultáltunk a magyarországi tervezőcégekkel, akik szintén útmutatást adtak a témában. A kapott eredmények azt mutatták, hogy az átjárhatóság kulcsa olyan hibrid jármü, mely egyaránt alkalmas mind a nagyvasúti, mind a metróüzemben való közlekedésre. Jelen cikk nem tér ki a kompatibilitásvizsgálat részleteire, ezt Molnár Levente TDK dolgozatának 5.3. fejezete [1] tartalmazza.

\section{A VIZSGÁLT VISZONYLATOK RÖVID BEMUTATÁSA}

Az M3-as metró Budapest leghosszabb és egyben legforgalmasabb metróvonala. A vonalon naponta megforduló utasok száma meghaladja a 600000 föt. Infrastruktúrájának felújítása jelenleg is folyamatban van, de elmondható, hogy a teljes szakasz kétharmadán már megtörténtek az átépítések. A jármüállomány 2018-ig bezárólag került felújításra, így viszonylag újnak tekinthető.

Ezzel szemben a Lajosmizsei vasútvonal (1.ábra) Budapest egyetlen nem villamosított elővárosi vasútvonala, ami egyben a legrosszabb állapotú is. A vasúti infrastruktúra, valamint a közlekedő jármüvek is elmaradnak a mai modern kor igényeitöl. A vonatok indulása 1 órás ütemben történik, a

\footnotetext{
${ }^{1}$ A kutatómunka elsősorban a nagyvasút, metró és a HÉV közötti átjárhatóságra koncentrált.
} 
reggeli csúcsidőben fél órás sủrítéssel, azonban ez a kedvezőtlen menetidővel társulva alacsony szolgáltatási színvonalat nyújt. A vasútvonal felújításának szüksége napjainkban egyre időszerübb, a Budapesti Agglomerációs Vasúti stratégia [2] is célként tüzte ki a Lajosmizsei vonal minél hamarabb történő korszerüsítését.

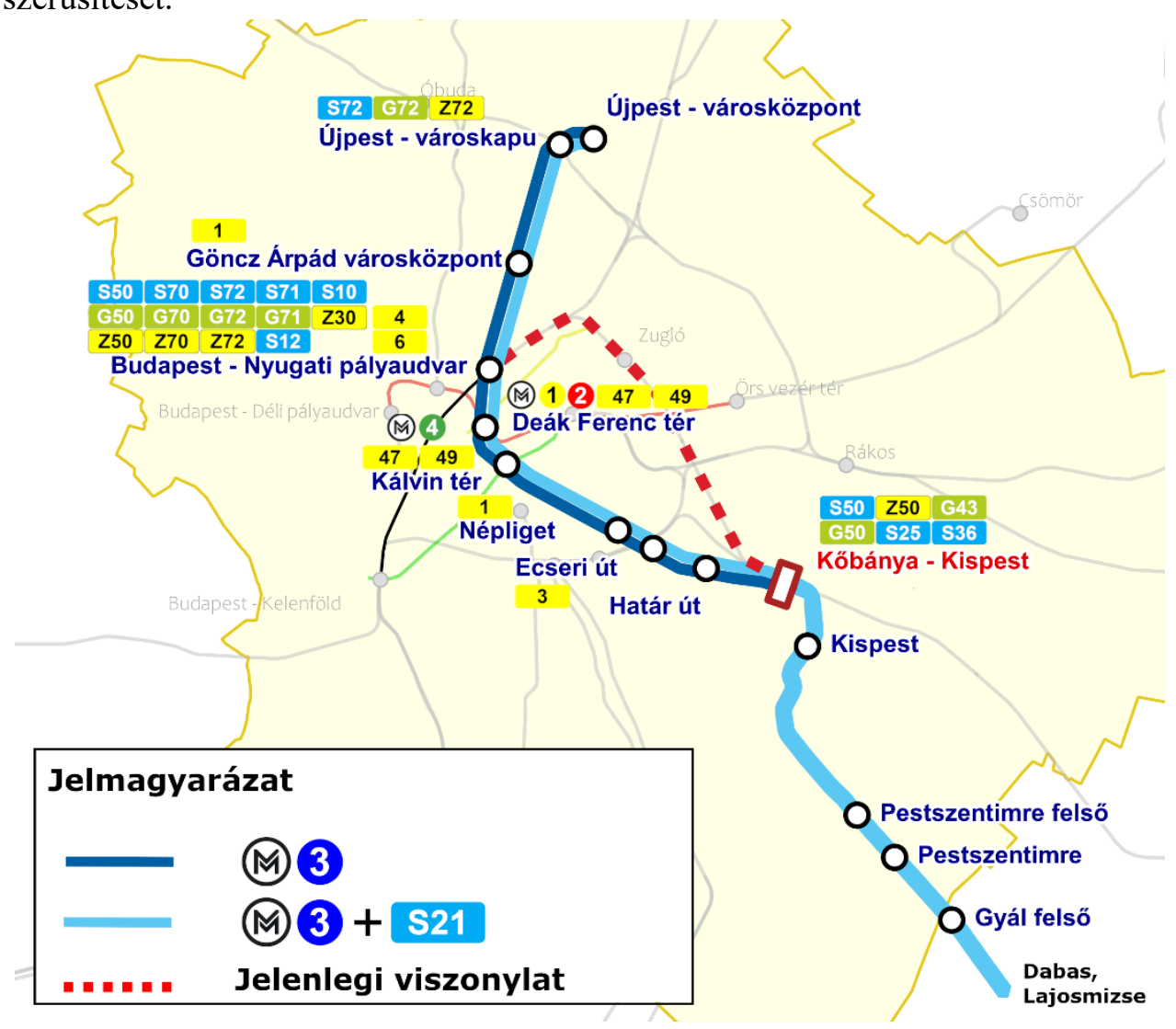

1. ábra: A lajosmizsei vasútvonal és az M3-as metró összekötése.

A vizsgálat során cél volt rámutatni arra, hogy egy alternatív lehetőség is adódhat a vasútvonal egyszerü felújításán túl és érdemes megragadni az alkalmat egy átjárható vasúti rendszer létesítésére.

A kiválasztás szempontjai közé tartozott a budapesti vasúthálózat jelenleg is korlátozott kapacitása. A Lajosmizséről közlekedő szerelvények Kőbánya-Kispest (KöKi) vasútállomásról a Budapest Cegléd vasútvonal vágányait használják, hogy elérjék a Nyugati pályaudvart. Ez a vonalszakasz már jelenleg is kapacitáshatáron üzemel, így ha a Lajosmizsei vonalon a korszerüsítés mellett a viszonylatok száma is növekszik - márpedig ez egyértelmüen cél - akkor a jelenlegi kétvágányú KöKi - Nyugati pályaudvar vonalszakasz kapacitása már nem lenne elegendő a forgalmi igények ellátására. A viszonylatok számának növelése esetén az egyszerübb megoldás az lenne, hogy a vonatok csak Kőbánya-Kispest vasútállomásig közlekednének, ahogy az a történelem során korábban is volt, és a reggeli betétjáratok szintén csak idáig közlekednek. Azonban ezzel a megoldással átszállásra kényszerítenénk a vasútvonal utazóközönségének jelentős részét. Másik lehetőség a Ceglédi vonal városi szakaszának a bővítése, ami jelentős költségekkel jár. Önmagában viszont a Lajosmizsei vasútvonal forgalma nem igényelné a Kőbánya-Kispest és a Nyugati pályaudvar között futó vasútvonal négyvágányúra építését.

Jelen cikk szerzői által javasolt összekötési megoldás egyben oldaná meg a problémát, miszerint a vasútvonalról érkező szerelvények döntően az M3-as metró vonalán közlekednének tovább speciális, e célra kialakított hibrid járművek segítségével, így nem terhelnék a Ceglédi vonal városi szakaszát. A vizsgálataink során kimutattuk, hogy az összekötés hatására az M3-as metrón utazók száma csak kis mértékben (5-10\%-al) növekedne, így a javasolt fejlesztésnek ebben a tekintetben nincs akadálya.

További szempont volt a kiválasztás során az is, hogy a metró- és a vasútvonal vágányai KőbányaKispest vasútállomáson egymás mellett futnak, ahol a két üzem közötti kapcsolat megvalósítható. Az 
M3-as metró nyomvonala a belvárosi kapcsolatok tekintetében is kedvezőbb, a vonal átszállási lehetőséget nyújt az összes budapesti metróra, valamint számos villamos és busz viszonylatra.

\section{A VIZSGÁLAT MÓDSZERTANA}

A forgalmi igények meghatározásához elöször menetrendi struktúrák felvázolására volt szükség. Saját online és helyszíni felmérések, illetve üzemeltetői (BKK, MÁV Zrt.) adatok, valamint analitikus forgalmi modell segítségével meghatároztuk a térségben keletkező utazási igényeket.

A kitöltők korosztályi megoszlása

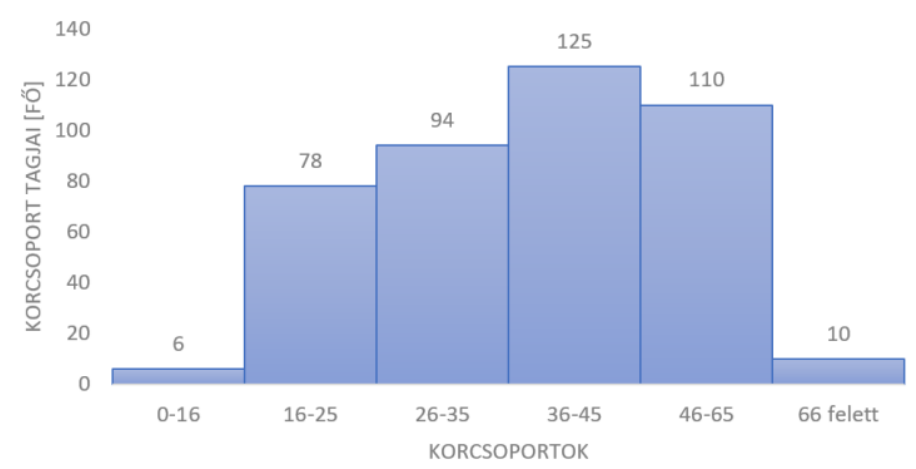

2. ábra: A kérdőív válaszadóinak korcsoport szerinti megoszlása (Google Form alapú online utazási igényfelmérés - 2020).

A kérdőív által kapott eredmények alapján, amit összesen 431 fö töltött ki, látható volt a létjogosultsága egy olyan vegyesüzem létrehozásának, ahol egyes szerelvények továbbra is a Nyugati pályaudvarra közlekednek, döntö többségük pedig az M3-as metró irányába. A kitöltők korcsoport szerinti megoszlását a 2. ábra szemlélteti.

Külön kérdés tért ki az összes szerelvény metró irányába való tovább közlekedésének esetére. Ebből kirajzolódott, hogy az utazóközönség jelentős része továbbra is a Nyugati pályaudvarnál szállna le, így nekik a jelenlegi útvonal lenne a kedvezőbb. (3.ábra) A Nyugati pályaudvar szerepe a későbbiekben természetesen folyamatosan csökkenne, ugyanis az utazás végpontja (munkavállalás helye, iskola) sokkal rugalmasabban kezelhető, ha az M3-as metró vonaláról minden föirány elérhető. A 3. ábra alapján látható, hogy az utazók jelentős része a belvárost szeretné elérni (Corvin-negyed - Nyugati Pályaudvar), de a jelentősebb átszállópontok forgalma is kiemelkedik (pl: Népliget, Göncz Árpád városközpont).

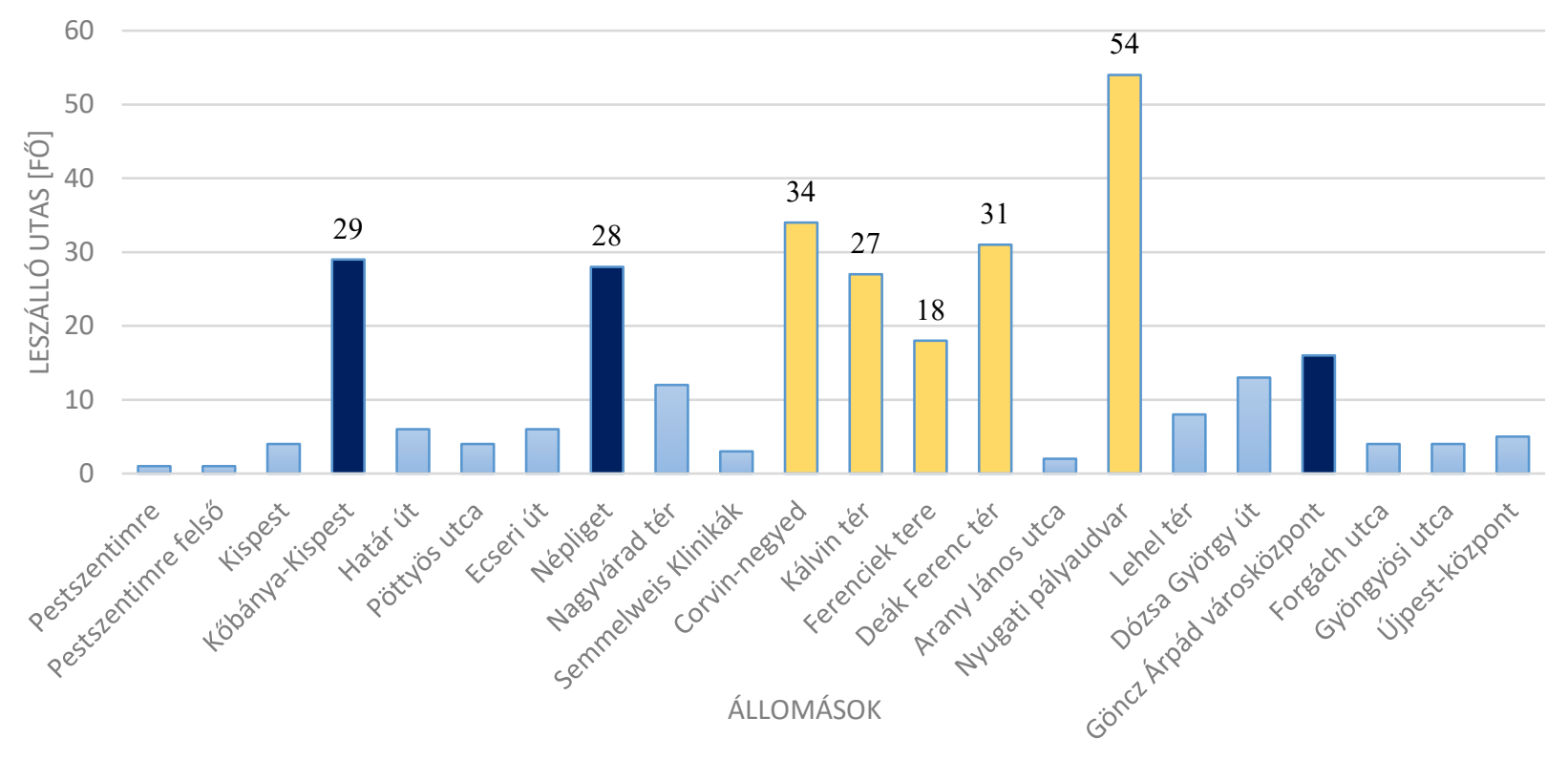

3. ábra: Leszállások helyének megoszlása Budapesten belül, ha a metró közvetlen kapcsolatot létesítene az agglomerációval (Google Form alapú online utazási igényfelmérés - 2020).

Annak érdekében, hogy a pontos utazási irányok kirajzolódjanak, a kérdőív gráf struktúrában került kialakításra, amelynek egyik részlete a 4. ábrán látható. A felépítésnek köszönhetően minden utasnak 
lekövethető volt a napi útvonala a kiindulási állomás és az úti célja között, a kérdéseket is ennek megfelelően kapták a kitöltők.

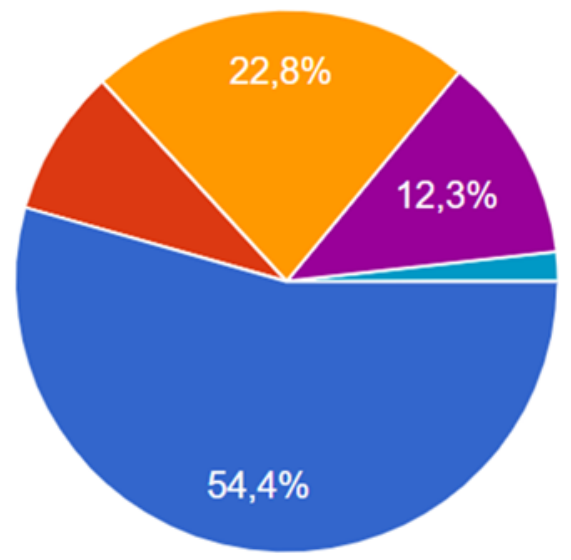

\author{
M3-as metróval \\ Vonattal Buda irányába [G43, S36] \\ Busszal \\ Roller, kerékpár, egyéb mobilitási \\ eszköz \\ Nem utazik tovább \\ Monor felé vonattal
}

4. ábra: Továbbutazások részaránya Kőbánya-Kispest vasútállomásról (Google Form alapú online utazási igényfelmérés 2020. május - 311 válasz alapján).

A következő lépésben a szükséges pályainfrastruktúra fejlesztések figyelembevételével több lehetséges menetrendi javaslat került kidolgozásra. Ezek a menetrendek már a kutatás során meghatározott, fejlesztésen átesett vonalra készültek, tartalmazva a metróval való összeköttetést is. A felépítésük számos tekintetben eltért egymástól, annak érdekében, hogy a lehető legkedvezőbb megoldás rajzolódjon ki. A menetrendek legfontosabb jellemzőit az 1. táblázat tartalmazza, részletesebb ismertetetés a TDK dolgozat 5.2.3. fejezetében található.

1. táblázat: A menetrendi javaslatok legfontosabb jellemzői.

\begin{tabular}{|c|c|c|c|c|}
\hline $\begin{array}{c}\text { Menetrendi } \\
\text { változatok }\end{array}$ & Menetrendi struktúra jellege & $\begin{array}{c}\text { Követési idö* } \\
\text { (perc) }\end{array}$ & $\begin{array}{c}\text { Nagyvasúti és } \\
\text { metróüzem } \\
\text { részaránya }\end{array}$ & $\begin{array}{c}\text { Infrastruktúra } \\
\text { igény }\end{array}$ \\
\hline I. & $\begin{array}{c}\text { nagyvasúti üzem a teljes vonalon, } \\
\text { független hibrid üzem Gyálig }\end{array}$ & $30+30$ & $50 \%$ hibrid üzem & $24 \mathrm{~km}$ \\
\hline II. & $\begin{array}{c}\text { zónázó nagyvasúti rendszer, gyáli hibrid } \\
\text { betétjáratokkal }\end{array}$ & $30+15$ & $67 \%$ hibrid üzem & $22 \mathrm{~km}$ \\
\hline III. & járatsürítés hibrid szerelvényekkel & $30+10$ & $67 \%$ hibrid üzem & $26 \mathrm{~km}$ \\
\hline IV. & $\begin{array}{c}\text { vegyesen hibrid és nagyvasúti } \\
\text { viszonylat, zónázó kialakítással, dabasi } \\
\text { meghosszabbítással }\end{array}$ & $30+20+20$ & $83 \%$ hibrid üzem & $40 \mathrm{~km}$ \\
\hline V. & $\begin{array}{c}\text { járatsürítés nagyvasúti szerelvényekkel, } \\
\text { Dabas és Inárcs-Kakucs végállomással }\end{array}$ & $30+20+20$ & $60 \%$ hibrid üzem & $37 \mathrm{~km}$ \\
\hline
\end{tabular}

*„Lajosmizséig közlekedő viszonylat” + „Gyálig közlekedő viszonylat” + „Ócsáig közlekedő viszonylat követési ideje"

A tervezett ütemes menetrendek azon alapultak, hogy az agglomeráció minden települése legalább fél óránként elérhető legyen vasúttal a fővárosból, összhangban a Budapesti Agglomerációs Vasúti Stratégia [2] célkitüzéseivel. A kidolgozott struktúrák közötti különbséget a szerelvények átlagos követési ideje, valamint a hibrid és nagyvasúti szerelvények aránya jelentette. Egyes esetekben a zónázó struktúra is megjelent a menetrendekben, mely a kapacitás elosztás tekintetében a legkedvezőbbnek bizonyult.

$\mathrm{Az}$ utazási igényfelmérésen alapuló menetrendváltozatok és az átjárhatóság helyi körülményeit figyelembe vevő müszaki változatokra egyszerüsített költség-haszon elemzést is készítettünk, a változatok összehasonlítása érdekében. Az elemzés a TDK dolgozat 5.4. fejezetében került részletezésre [1].

Az összesített eredmények alapján minősítettük a vizsgált gyorsvasúti rendszerek átjárhatósággal elérhető szolgáltatási színvonal változását, valamint a vizsgált projekt megvalósíthatóságát. 


\section{FORGALMI VIZSGÁLAT PTV VISUM SZOFTVERREL²}

A vizsgálati helyszín kiterjedésének nagysága, a különböző közlekedési módok egymásra hatásának számszerüsíthetősége, valamint a tervezett fejlesztés jelentősége miatt a vizsgálathoz analitikus forgalmi modellre volt szükség. Ennek segítségével meg lehetett becsülni a fejlesztések hatására várható utasszámnövekedést, valamint össze lehetett hasonlítani a tervezett, új menetrendi javaslatokat egymással.

A munka során a BKK Zrt. Egységes Forgalmi Modelljének (a továbbiakban EFM) a SV04.04-es verziója került használatra. [3] A modell többek között tartalmazza Budapest agglomerációjának közúti és vasúti hálózatát a jelenlegi közforgalmú közlekedés viszonylataival együtt, követési idő alapú struktúrában. A budapesti modell a jelenlegi állapot mellett számos jövőbeli forgatókönyvet tartalmaz. Az elkészített elemzések során minden változat esetén a 2030-as távlati modell került alkalmazásra.

Az EFM a PTV AG. Visum nevü szoftver környezetében került megvalósításra. Felépítése a klasszikus 4 lépcsős modellezési eljáráson alapul. Az SV04.04 modell verzióban az első három lépcsőt (forgalom keltés, -szétosztás, eszközválasztás) külön álló igénymodellezési munkarészek alkotják, melyek eredményeit a hálózati modellbe táplálják, s az említett modellező szoftver pedig ezen adatok segítségével végzi el a negyedik lépcsőt, a forgalmi ráterhelést.

\subsection{A TERVEZETT VISZONYLAT MODELLEZÉSE}

Az EFM-ből kiindulva, lokális módosításokon keresztül elkészítettük a tervezett új vonalat is tartalmazó forgalmi modellt, mely kapcsolatot ad a két vasútüzem között Köbánya-Kispest vasútállomáson. A modell többi része az EFM-hez képest változatlan formában maradt és a további futtatások során annak teljes - Budapest és agglomerációját is tartalmazó - egésze kiértékelésre került.

Az EFM felépítésében különbséget tesz a közösségi közlekedés módozatai között (Vasút, HÉV, Villamos, Metró stb.). Ennek a különbségnek az egyik szembetűnő megnyilvánulása a felszállási büntetés („mode penalty”), avagy adott közlekedési mód népszerüsége az utasok közt. Ezen hatás utazási idő növekményben kerül kifejezésre, ami magában foglalja az adott módra történő átlagos várakozási időt is. Így egy metró viszonylat esetén értéke lényegesen kisebb, mint egy elővárosi, hozzávetőlegesen ritkábban járó, hagyományos MÁV viszonylatnak. A kutatás során további finomítási lehetőséget adó felmérések elvégzésére nem volt lehetőségünk, ezért az EFM beállításait meghagytuk: az új vegyes viszonylatok esetén és az új hibrid szerelvénynél a metró, a nagyvasúti szerelvények esetén a vasútra vonatkozó felszállási büntetés értéke volt érvényben.

Az útvonal megszerkesztése után a szoftver menetrendi szerkesztőjébe betáplálásra kerültek a kiszámolt új menetidők, majd ezek alapján a követési idők értékei. Az EFM modell kizárólag a követési idők alapján dolgozik, így sok esetben az alapvetően nem ütemezhető menetrend ütemessé alakítása külön figyelmet igényelt.

\subsection{AZ ÚJ INTEGRÁLT VISZONYLAT HATÁSVIZSGÁLATA}

Annak érdekében, hogy a menetrendi javaslatok összehasonlíthatóak legyenek, mindegyik egyesével betáplálásra került a forgalmi modellbe. A ráterhelések lefutása után megállapítható volt, hogy mely esetben érhető el a legnagyobb utasszám növekedés, a költségek és a hasznok összeszámlálása során is ez lett figyelembe véve. Az átjárható rendszerrel elérhető legkedvezőbb eredményt az 5. ábra tartalmazza. Az ábrán szemléltetésre került a hasonló szolgáltatási szinttel rendelkező fejlesztett nagyvasúti viszonylat is, valamint új megálló javaslatok is megjelennek.

\footnotetext{
${ }^{2}$ A kutatás során a PTV Visum teljeskörü változata állt rendelkezésre, így a jelentős méretű hálózat modellezése sem jelentett problémát.
} 
A szemléltetett átjárható rendszer esetén a menetrend gerincét hibrid rendszerü jármüvek alkotják 30 perces követéssel, valamint ehhez jött hozzá a nagyvasúti szerelvényekből kiállított betétjáratok, amelyek végállomása Ócsa és Dabas volt. A betétjáratoknak köszönhetően a Budapesti szakaszon a követési idő 5 percre adódott. A többi változat bemutatását a TDK dolgozat 5.3.3. fejezete tartalmazza [1].
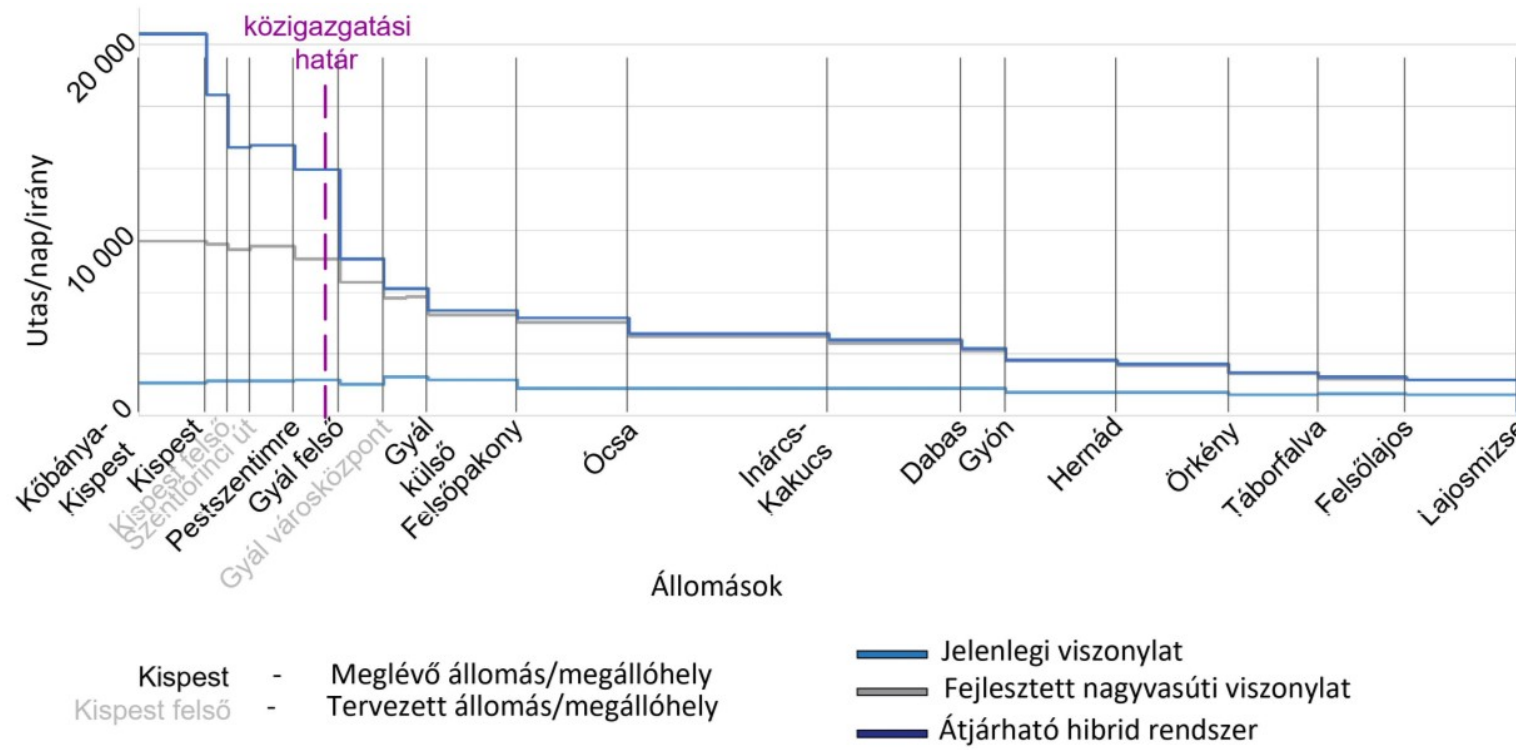

5. ábra: Az integrált közlekedésfejlesztés által elérhető, legmagasabb utasszám növekedés becsült értéke Budapest közigazgatási határán belüli és kívüli területeken.

Az értékek alapján elmondható, hogy az eredeti állapothoz képest Budapest közigazgatási határán belül (Köbánya-Kispest - Gyál) több mint tízszeres utasszámnövekedés érhető el, ami a helyi közlekedés teljes átrendeződésének köszönhető. A térségből a belváros irányába közlekedők jelentős része utazik az M3-as metróval, amit a közlekedők jelenleg BKK busz viszonylatok (84E, 84M, 89E, 94E, 94M, 184, 284E, 294E, 294M) segítségével érnek el. A 6. ábra alapján látható, hogy a lakosság jelentős része a Nagykőrösi úti buszkorridort veszi igénybe az M3-as metróhoz történő eljutáshoz. 


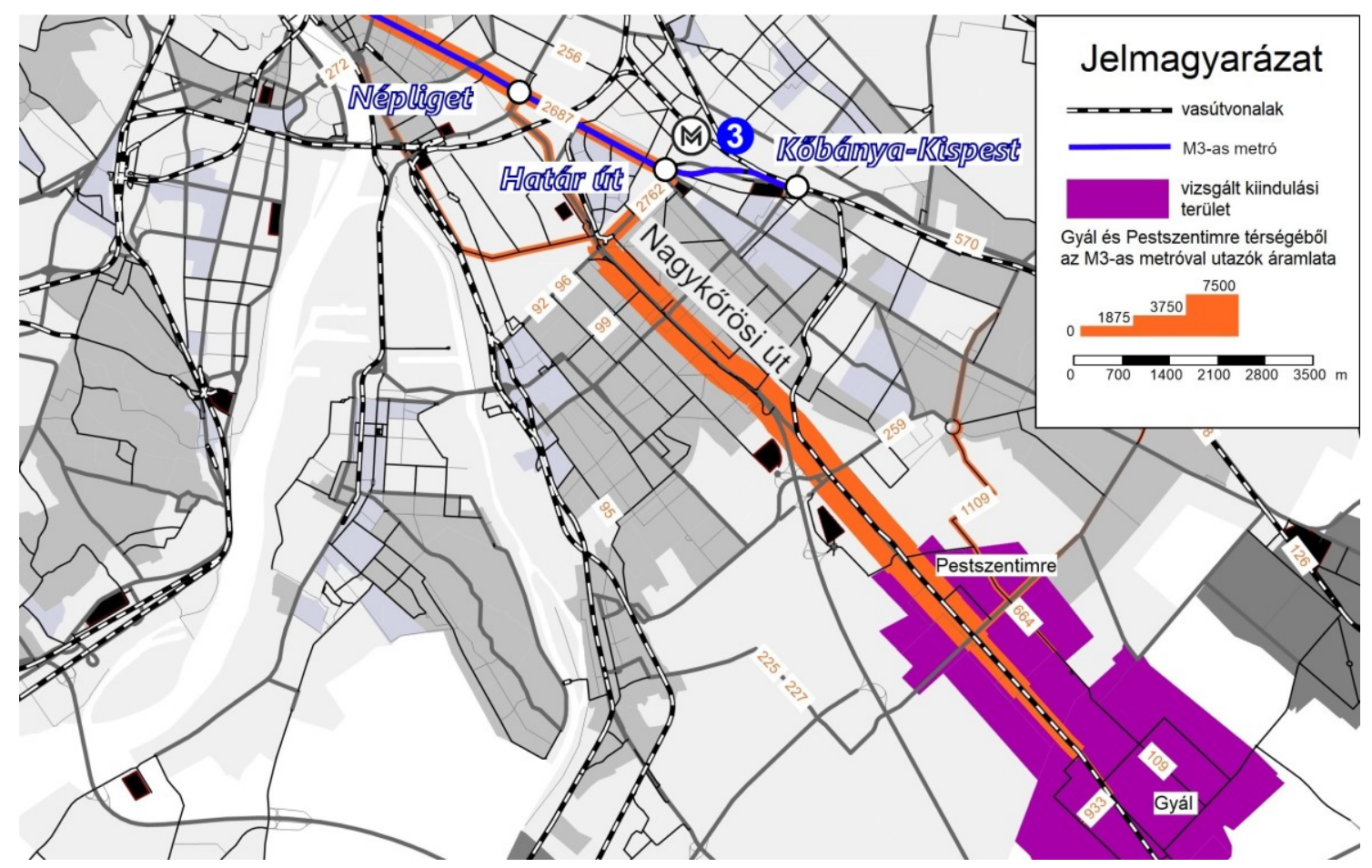

6. ábra: A Pestszentimre és Gyál térségéből az M3-as metróval utazók áramlata (jelenlegi állapot).

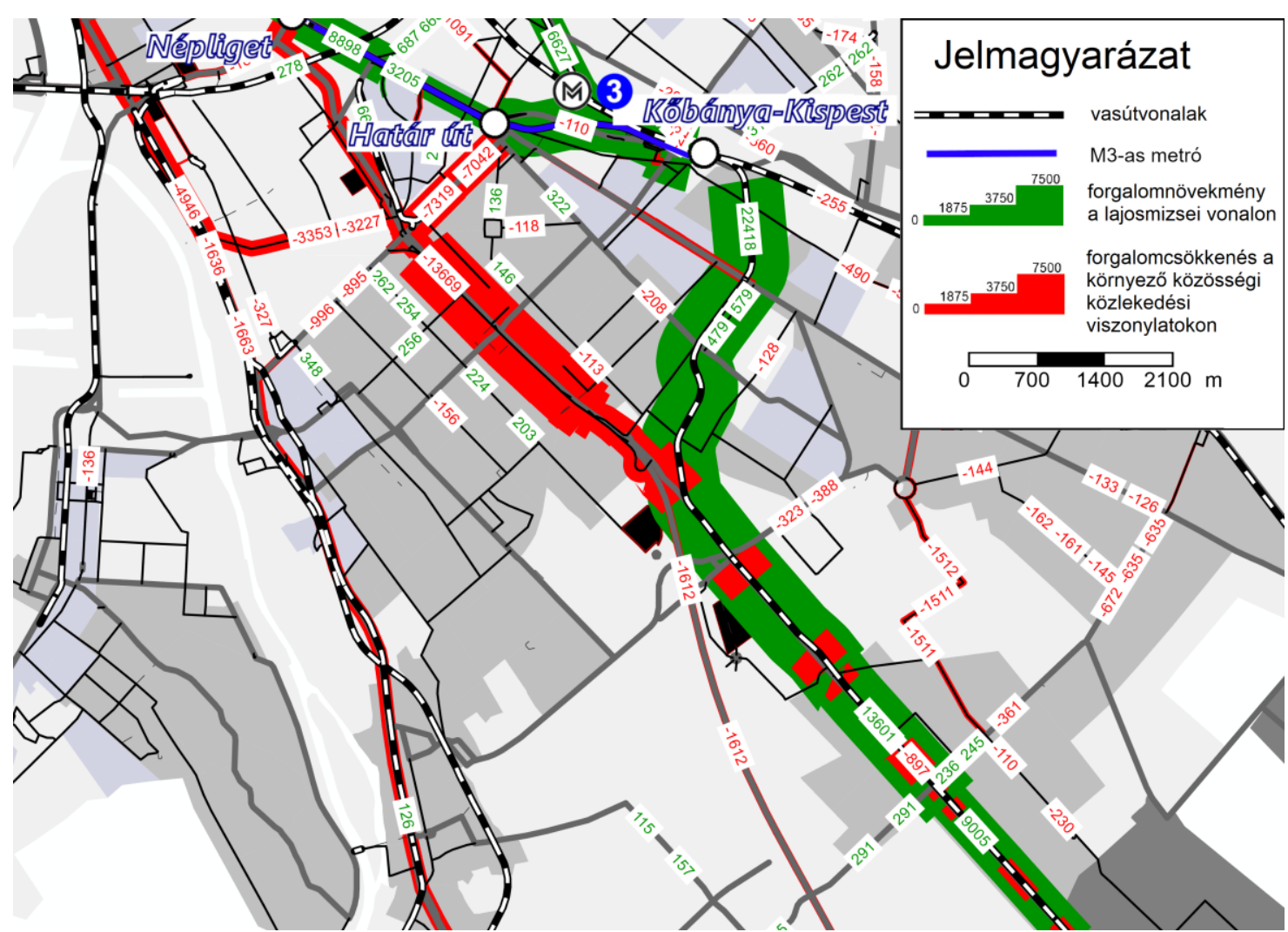

7. ábra: Pestszentimre és Gyál térség közösségi közlekedésének átrendeződése kölcsönösen átjárható integrált közlekedési rendszer megvalósulása esetén. A feltűntetett értékek a Budapest irányába tartó napi utasforgalmat szemlélteti. (A vasútvonal mentén látható a piros és a zöld sávok váltakozása a két párhuzamosan futó útvonal egybemosódásának következménye).

A javasolt fejlesztés hatására a MÁV szerelvények által is kölcsönösen átjárható hibrid metró üzem kitolódna Pestszentimre és Gyál térségébe, így az utazóközönség már itt fel tudna szállni a nagyvasút 
nyomvonalán közlekedő integrált viszonylatokra, így számos E jelü buszviszonylat megszüntethető a környéken. Az érintett terület forgalmi átrendeződését a 7. ábra szemlélteti.

A vasútvonal fejlesztése kedvezö átrendeződést mutatott az agglomerációs területeken is, ahol számos VOLÁN buszjárat kerülhetne kiváltásra. A felszabaduló erőforrásokat célszerü lenne a jövőben az új vasútvonalra ráhordó járatként üzemeltetni, a kényelmes csatlakozások érdekében közös peronon történő átszállási lehetőséget biztosítva.

A vizsgált során alkalmazott EFM modell (SV.04. kiadás) az egyéni és a közösségi közlekedési mód közötti váltást felépítéséből adódóan nem tudja a hálózati modellen belül kezelni, ezekhez további számítások szükségesek a Visum szoftverkörnyezeten kívül. Mivel a modell ilyen irányú fejlesztése a munka keretein jelentősen túlmutatott volna, a módválasztás eltolódása (modal shift) mellőzésre került a számításokból. Így az eredmények kizárólag azt szemléltetik, hogy a jelenlegi utazási igények mellett a közösségi közlekedésen belül milyen átrendeződések várhatóak a jövőre nézve. Ezzel alábecsülve a távlati hasznokat, melyek további modell fejlesztést követően várhatóan fokozottabb értékkel lennének kimutathatóak.

A kapott eredmények alapján becsülhető volt az utasszám növekmény is az M3-as metró vonalán. Molnár Levente előzetes vizsgálatai azt mutatták, hogy utas kapacitás szempontból nincs akadálya a metró és a vasútvonal összekötésének, ugyanis a megnövekedett forgalom jelentős része az a városon belüli közlekedési folyosók átrendeződéséből adódik. Azok az utazók, aki eddig a térségből busszal közlekedtek a Határ úti metróállomásra és ott szálltak fel a metróra, már Pestszentimre - Gyál területén szállnának fel a szerelvényekre. A metró legforgalmasabb állomásán végzett helyszíni számítások alátámasztották, hogy növekvő utasforgalom esetén két szerelvény között kiürül az állomások peronja. Ez azt jelenti, hogy az állomások tekintetében is van még szükséges kapacitási tartalék.

Mint minden, új viszonylat megnyitásával foglalkozó tanulmány esetén, jelen munka során is a jövőben várható utazási idő rövidüléssel és egyéb járulékos pozitív hatásokkal ${ }^{3}$ számoltunk.

A 2. táblázatban Gyál felsőről a Deák Ferenc térre utazók menetidő az összehasonlítása látható. A jelenlegi állapot esetén a leggyorsabb eljutási lehetőséget a busz szolgáltatja, ezért a fejlesztett változat ezzel került összehasonlításra.

2. táblázat: Eljutási idők jelenleg és a javasolt fejlesztés esetén Gyál felsőről a Deák Ferenc Térre.

\begin{tabular}{|c|c|}
\hline \multicolumn{2}{|l|}{ Jelenlegi állapot szerint: } \\
\hline $\begin{array}{l}\text { Gyál felsőröl } 20 \text { perc busz a Határ útra, ott } 3 \text { perc séta a metróig majd } 2 \text { perc átlagos } \\
\text { várakozási idő, majd } 14 \text { perc utazás az M3-as metróval a Deák Ferenc térre }\end{array}$ & 39 perc \\
\hline \multicolumn{2}{|l|}{ A javasolt integrált közlekedési rendszer esetén: } \\
\hline $\begin{array}{c}15 \text { perc Gyál felsőröl Köbánya-Kispestre, majd onnan átszállás nélkül } 16 \text { perc a } \\
\text { Deák Ferenc térre }\end{array}$ & 31 perc \\
\hline
\end{tabular}

A fejlesztés utazásonként 8 perc megtakarítást jelent, ám ezzel a számértékkel nem fejezhető ki az a valódi nyereség, amelyet az utazók eddig az átszállások következtében szenvedtek el.

Ha figyelembe vesszük, hogy az esetek többségében ezt az utazást az ellenkező irányba is megtörténik, akkor éves szinten 252 munkanappal számolva közel 67 órát takarítunk meg egy utazóra vetítve.

A költségek és hasznok összevetése során is ezek az időmegtakarítások lettek figyelembe véve, 10 kiválasztott forgalmas Budapesti csomópontra összegezve. A kapott időmegtakarítás végül fel lett szorozva a térségre jellemző átlagos jövedelemmel, amiböl kiderül, hogy naponta hány Forint megtakarítást érhetünk el.

\footnotetext{
${ }^{3}$ nemzetgazdasági haszon, felszabaduló erőforrások, ...
} 


\section{5. ÖsSZEFOGLALÁs}

Az utasszám adatok (5. ábra) egyértelmüen igazolták, hogy mindenképpen érdemes és célravezető a Lajosmizsei vasútvonal és az M3-as metró átjárhatóságával foglalkozni. A jelen cikkben javasolt fejlesztések következtében lényegesen kevesebb (BKK és VOLÁN) jármüvel ki lehet szolgálni az utasforgalmi igényt, ami kisebb üzemköltséggel jár. Ökológiai szempontból is kedvezőbb a térség kötöttpályás közlekedésének előnyben részesítése, az alacsony jármüszám kevesebb károsanyag kibocsájtást is jelent, illetve az egyéb közúti közlekedést is kevésbé akadályozza, melynek saját kibocsájtása is csökkenhet ezáltal. A müszak kompatibilitás vizsgálat eredményei azt igazolták, hogy nincs technikai korlátja a két rendszer összekötésének, hibrid járművek üzemeltetésével a kapcsolat biztosítható a két vasútüzem között.

Amíg a városi területeken belül egyértelmủen levonható a metróval való közvetlen kapcsolat pozitív hatása, addig a külső szakaszokon nem jelentkezett kiemelkedő utasszám emelkedés. Ennek következtében érdemes gazdaságilag megfontolni az átjárható rendszer üzemét az agglomeráció területén, így a jövőben fő feladat megtalálni azt a települést a vasútvonalon, ameddig érdemes a hibrid viszonylatokat üzemeltetni.

A jelen publikációban megjelenő kutatások az ITM NKFIA által nyújtott TKP2020 IKA támogatásból, az NKFIH által kibocsátott támogatói okirat alapján valósultak meg (projektazonosító: TKP2020 BME-IKA-VIZ).

\section{IRODALOMJEGYZÉK}

[1]: Molnár, L. 2020: Budapesti városi, - és elővárosi gyorsvasúti rendszerek integrált közlekedésfejlesztési lehetőségeinek vizsgálata - Az M3-as metró és a 142-es sz. Lajosmizsei vasútvonal kölcsönös átjárhatóságának részletes vizsgálata - http://tdk.bme.hu/EMK/DownloadPaper/Budapestivarosi-es-elovarosi-gyorsvasuti

[2]: BAVS - Budapesti Agglomerációs Vasúti Stratégia - https://budapestvasut2040.hu/

[3]: EFM - Egységes Forgalmi Modell - https://bkk.hu/fejlesztesek/egyseges-forgalmi-modell/ 